\title{
Geochronological constraint on the brittle-plastic deformation along the Hatagawa Fault Zone, NE Japan
}

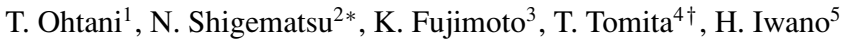 \\ ${ }^{1}$ Department of Civil Engineering, Gifu University, Yanagido 1-1, Gifu, Gifu 501-1193, Japan \\ ${ }^{2}$ Geological Survey of Japan, AIST, Central 7, 1-1-1 Higashi, Tsukuba, Ibaraki 305-8567, Japan \\ ${ }^{3}$ Faculty of Education, Tokyo Gakugei University, 4-1-1 NukuiKita-machi, Koganei-city, Tokyo 184-8501, Japan \\ ${ }^{4}$ Institute of Geoscience, University of Tsukuba, Tsukuba, Ibaraki 305-8571, Japan \\ ${ }^{5}$ Kyoto Fission-Track Co., Ltd., 44-4 Minamitajiri-cho, Omiya, Kita-ku, Kyoto 603-8832, Japan
}

(Received June 9, 2004; Revised November 25, 2004; Accepted December 3, 2004)

\begin{abstract}
K-Ar ages and fission-track ages of granitic rocks in the Hatagawa Fault Zone (HFZ), NE Japan were measured to examine the cooling history of the HFZ. The HFZ is an NNW-SSE trending fault zone in the Cretaceous granitic rocks, and consists of a conspicuous cataclasite and two types of mylonite with a sinistral sense of shear. The cataclasite zone is NNW-SSE trending and continuous over at least $40 \mathrm{~km}$ with a maximum thickness of $100 \mathrm{~m}$. One type of mylonite is low-T mylonite, which is mainly developed for a length of $6 \mathrm{~km}$ along the HFZ. The other is high-T mylonite, which is widely distributed in the HFZ. Most of K-Ar ages of hornblende and biotite from granitic rocks are about $110 \mathrm{Ma}$ and show no obvious differences along the strike of the HFZ or among different granite bodies. This implies that the granitic rocks in the HFZ have a similar cooling history and cooled rapidly from closure temperature of hornblende to that of biotite. Zircon fission-track analysis shows little possibility of reheating of the granitic rocks. This supports the formation of cataclasite and mylonite during the cooling of the granitic bodies. Fission-track ages of zircon and apatite from the samples in and near the areas where the low-T mylonite is developed are older than those for other areas. Infiltration of near-surface derived water into the low-T mylonite after plastic deformation may account for the accelerate cooling of granitic bodies. Key words: Hatagawa Fault Zone, brittle-plastic deformation, K-Ar ages, fission-track ages.
\end{abstract}

\section{Introduction}

The thermal history along a fault strongly affects faulting history, and fault displacement often governs the thermal history along the fault (e.g. Stöckhert et al., 1999). Recent studies of the Hatagawa Fault Zone (HFZ), NE Japan, have revealed that (1) cataclasite and mylonite formed within a limited period between $126 \pm 6$ and $98.1 \pm 2.5 \mathrm{Ma}$ (Tomita et al., 2002), (2) repeated episodes of plastic deformation and fracturing occurred in the mylonite zone (Takagi et al., 2000; Tomita et al., 2002; Shigematsu et al., 2004), (3) cataclasite formed at temperature above $220^{\circ} \mathrm{C}$ (Tomita et al., 2002) and (4) the lowest estimation of deformation temperature of mylonite is $300^{\circ} \mathrm{C}$ (Shigematsu et al., 2003). As no obvious discontinuities of time and temperature are found between cataclasite and mylonite formation, the fault rocks along the HFZ passed through the brittle-plastic transition zone (Takagi et al., 2000; Tomita et al., 2002; Shigematsu et al., 2004). Shigematsu et al. (2003) deduced that heterogeneous distribution of plastic deformation in the brittleplastic transition along the HFZ resulted in a significant

*Present address: Department of Earth Sciences, Chiba University, 133, Yayoi-cho, Inage-ku, Chiba 263-8522, Japan.

${ }^{\dagger}$ Present address: FDC Incorporated company, 111-2 Arakawaoki, Tsuchiura, Ibaraki 300-0873, Japan.

Copy right (C) The Society of Geomagnetism and Earth, Planetary and Space Sciences (SGEPSS); The Seismological Society of Japan; The Volcanological Society of Japan; The Geodetic Society of Japan; The Japanese Society for Planetary Sciences; TERRAPUB stress concentration and the nucleation of large earthquakes. The HFZ enables us to examine the relation between the cooling history and the heterogeneity of plastic deformation in the brittle-plastic transition, especially with the nucleation zone of the large earthquakes. K-Ar dating and fission-track dating of granitic rocks were, therefore, performed in this study.

\section{Hatagawa Fault Zone}

The HFZ is at the eastern margin of the Abukuma Mountains, NE Japan (Fig. 1), and trends in the NNW-SSE direction (Watanabe et al., 1953; Sendo, 1958). The South Kitakami belt is located to the east of the HFZ, and the Abukuma belt is to the west (Kubo and Yamamoto, 1990). The HFZ is located at the boundary of these two belts. The South Kitakami and the Abukuma belts around the HFZ mainly consist of magnetite-bearing and magnetitefree Cretaceous granitic rocks respectively. A conspicuous cataclasite zone with a maximum thickness of about $100 \mathrm{~m}$ extends continuously in the HFZ for at least $40 \mathrm{~km}$ (Fig. 2) (Tomita et al., 2002). Mylonite zones with a sinistral sense of shear are heterogeneously distributed with a maximum thickness of $1 \mathrm{~km}$ along the HFZ (Shigematsu and Yamagishi, 2002). The foliation strikes N-S to NE-SW and dips subvertically; the stretching lineation is subhorizontal. Quartz microstructures in the mylonite have been subdivided into two groups, microstructures A and B (Fig. 3) (Shigematsu and Yamagishi, 2002). Microstructure A is 


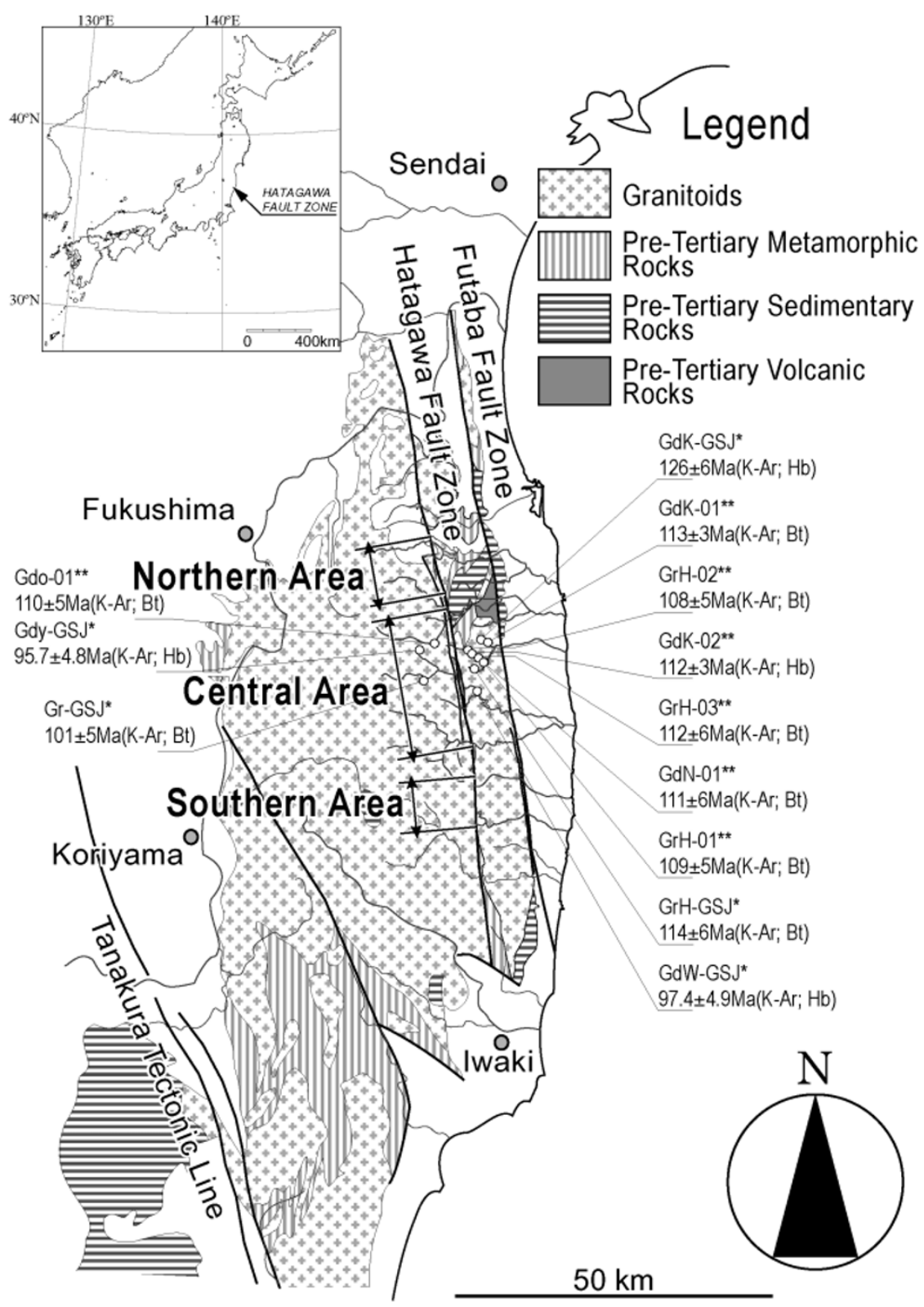

Fig. 1. Regional geological map of the Abukuma Mountains, NE Japan and K-Ar ages of samples away from the Hatagawa Fault Zone (Kubo et al., 1990; Tomita et al., 2002). * and ** represent the data from Kubo et al. (1990) and Tomita et al. (2002), respectively. Hb and Bt indicate hornblende and biotite, respectively. Three areas along the Hatagawa Fault Zone, northern area, central area and southern area are shown in Fig. 2.

characterized by quartz grains exhibiting core and mantle structure (White, 1976) and a type I crossed girdle fabric pattern resulting from subgrain rotation dynamic recrystallization. Microstructure B is characterized by quartz grains with a Y-maximum fabric pattern caused by both progressive subgrain rotation and grain boundary migration. The mylonite with quartz microstructure $\mathrm{A}$ is mainly developed for a length of $6 \mathrm{~km}$ along the strike of the HFZ, while the mylonite with quartz microstructure $\mathrm{B}$ is widely distributed in the HFZ (Shigematsu et al., 2003). Shigematsu and Yamagishi (2002) calculated deformation temperatures of these mylonites by the thermometer after Stormer (1975), and Shigematsu et al. (2003) recalculated them by the twofeldspar thermometer (Whitney and Stormer, 1977). The recalculated temperatures generally range from $300^{\circ} \mathrm{C}$ to $360^{\circ} \mathrm{C}$ for mylonite with quartz microstructure $\mathrm{A}$ and from $340^{\circ} \mathrm{C}$ to $480^{\circ} \mathrm{C}$ for the mylonites with quartz microstructure B. Some mylonites with quartz microstructure A exhibit deformation temperatures ranging between $340^{\circ} \mathrm{C}$ to $480^{\circ} \mathrm{C}$. In this paper, the mylonites which exhibit deformation temperature ranging from $300^{\circ} \mathrm{C}$ to $360^{\circ} \mathrm{C}$ are called low-T mylonites, and those ranging from $340^{\circ} \mathrm{C}$ to $480^{\circ} \mathrm{C}$ are high-T mylonites.

\section{Geochronological Results}

Nine samples were collected for K-Ar and fission-track datings to constrain the cooling history of the HFZ (Fig. 2). These samples were taken from undeformed granitic rocks near the mylonite zone or weakly deformed granitic rocks in the mylonite zone. K-Ar ages of 8 samples and fission-track ages of 4 samples were determined in this study (Tables 1 and 2). Some geochronological results in the region of 


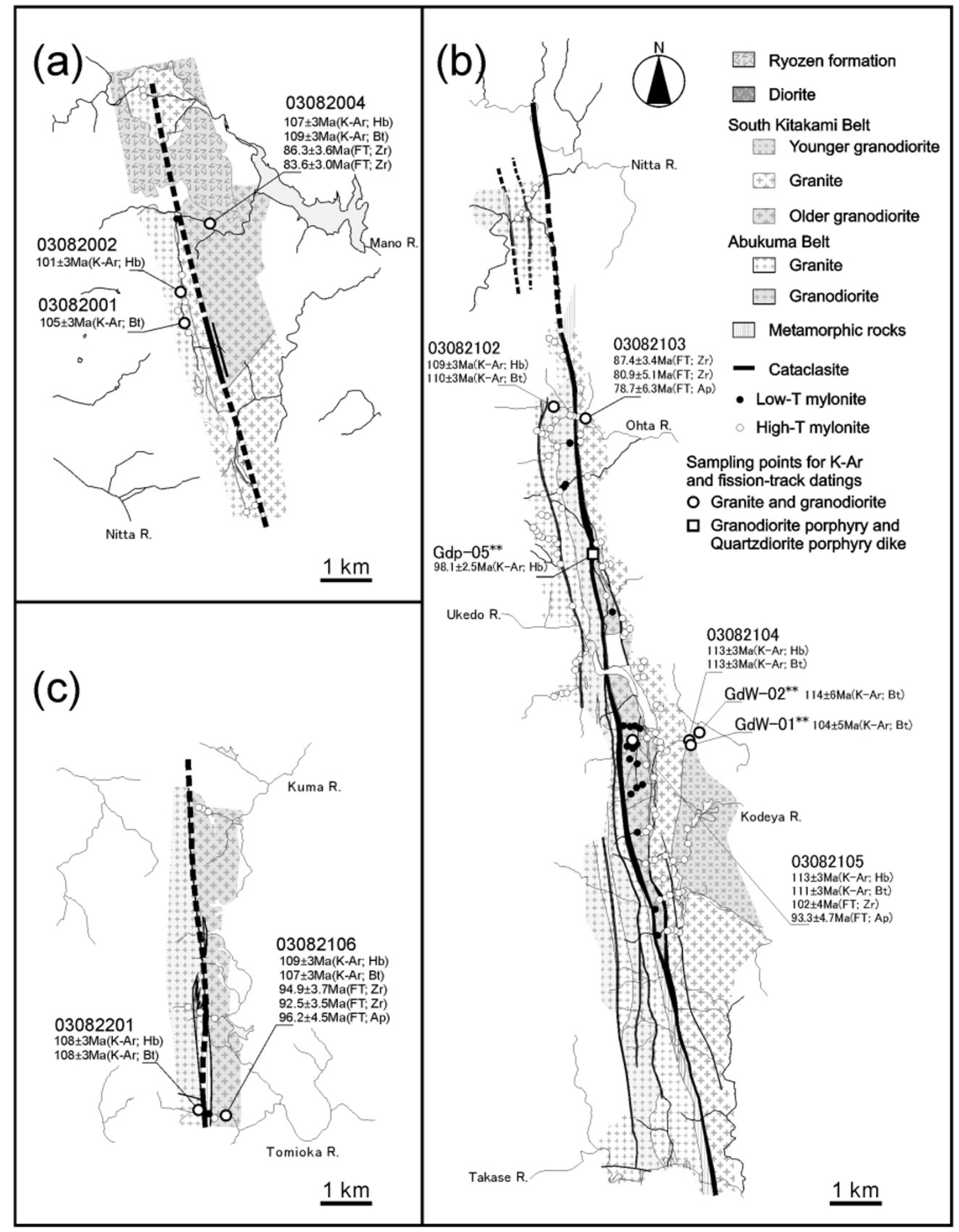

Fig. 2. Simplified geological map along the Hatagawa Fault Zone, showing distribution of low-T and high-T mylonites and K-Ar and fission-track ages. Compiled from Kubo et al. (1994), Yanagisawa et al. (1996) and Shigematsu and Yamagishi (2002). Ages with* and ** represent the data from Kubo et al. (1990) and Tomita et al. (2002), respectively. Hb, Bt, FT, Zr, Ap indicate hornblende, biotite, fission-track, zircon and apatite, respectively. (a) Northern area, (b) Central area and (c) Southern area.

the Abukuma Mountains have previously been reported by Kubo et al. (1990) and Tomita et al. (2002). Here, we combine these published results with those of our study.

$\mathrm{K}-\mathrm{Ar}$ ages of hornblende from samples of granitic rocks in the HFZ range from $113 \pm 3$ to $101 \pm 3 \mathrm{Ma}$, and those of biotite show a range from $114 \pm 3$ to $104 \pm 5$ Ma (Fig. 2). Most samples of granitic rocks newly measured in this study show almost similar K-Ar ages of ca. $110 \mathrm{Ma}$, allowing for the error range of the dating, except for a few samples. Six samples have yielded both $\mathrm{K}-\mathrm{Ar}$ ages of hornblende and biotite from a single sample (03082004, 03082102, 03082104, 03082105, 03082106 and 03082201). In these samples, the difference between K-Ar ages of hornblende and biotite is not significant. The samples from the western 
Table 1. K-Ar ages from the granitic rocks in the Hatagawa Fault Zone (HFZ). * and ** represent the data from Kubo et al. (1990) and Tomita et al. (2002), respectively. $\mathrm{Hb}$ and Bt indicate hornblende and biotite, respectively. Samples from this study were analyzed at Geospace Science Co., Ltd.

\begin{tabular}{|c|c|c|c|c|c|c|}
\hline & Sample No. & $\begin{array}{c}\text { Material } \\
\text { Analyzed }\end{array}$ & $\begin{array}{c}{ }^{40} \mathrm{Ar} \mathrm{rad} \\
\left(\times 10^{-5} \mathrm{scc} / \mathrm{g}\right)\end{array}$ & $\begin{array}{c}{ }^{40} \mathrm{Ar} \mathrm{rad} \\
(\%)\end{array}$ & $\begin{array}{c}\mathrm{K} \\
(\%)\end{array}$ & $\begin{array}{c}\text { Isotopic Age } \\
(\mathrm{Ma})\end{array}$ \\
\hline \multicolumn{7}{|c|}{ Granitic rocks on eastern side of the HFZ } \\
\hline \multirow{2}{*}{\multicolumn{2}{|c|}{ * GdW-GSJ }} & $\mathrm{Hb}$ & 0.430 & 86.8 & 1.14 & \multirow{2}{*}{$97.4 \pm 4.9$} \\
\hline & & & 0.461 & 87.2 & 1.15 & \\
\hline \multirow{2}{*}{\multicolumn{2}{|c|}{ ** GdW-01 }} & $\mathrm{Bt}$ & 1.64 & 93.3 & 4.02 & \multirow{2}{*}{$104 \pm 5$} \\
\hline & & & 1.72 & 93.5 & 4.02 & \\
\hline \multirow{2}{*}{\multicolumn{2}{|c|}{$* *$ GdW-02 }} & $\mathrm{Bt}$ & 1.63 & 96.1 & 3.50 & \multirow{2}{*}{$114 \pm 6$} \\
\hline & & & 1.58 & 95.4 & 3.52 & \\
\hline \multirow{2}{*}{\multicolumn{2}{|c|}{ * GrH-GSJ }} & $\mathrm{Bt}$ & 3.10 & 86.6 & 0.419 & \multirow{2}{*}{$114 \pm 6$} \\
\hline & & & 3.08 & 92.4 & 0.430 & \\
\hline \multirow{2}{*}{\multicolumn{2}{|c|}{$* *$ GdN-01 }} & $\mathrm{Bt}$ & 2.43 & 93.4 & 5.49 & \multirow{2}{*}{$111 \pm 6$} \\
\hline & & & 2.46 & 93.6 & 5.46 & \\
\hline \multirow{2}{*}{\multicolumn{2}{|c|}{ ** $\mathrm{GrH}-01$}} & $\mathrm{Bt}$ & 1.92 & 93.8 & 4.33 & \multirow{2}{*}{$109 \pm 5$} \\
\hline & & & 1.85 & 94.6 & 4.34 & \\
\hline \multirow{2}{*}{\multicolumn{2}{|c|}{$* * \frac{\mathrm{GrH}-02}{4}$}} & $\mathrm{Bt}$ & 1.92 & 83.1 & 4.47 & \multirow{2}{*}{$108 \pm 5$} \\
\hline & & & 1.92 & 88.4 & 4.44 & \\
\hline \multirow[t]{2}{*}{$* *$} & GrH-03 & $\mathrm{Bt}$ & 3.09 & 97.5 & 6.83 & \multirow{2}{*}{$112 \pm 6$} \\
\hline & & & 3.06 & 97.4 & 6.81 & \\
\hline \multirow[t]{2}{*}{$*$} & GdK-GSJ & $\mathrm{Hb}$ & 0.419 & 86.9 & 0.84 & \multirow{2}{*}{$126 \pm 6$} \\
\hline & & & 0.430 & 92.4 & 0.84 & \\
\hline \multirow[t]{2}{*}{ *** } & GdK-01 & $\mathrm{Bt}$ & 2.84 & 93.2 & 6.22 & \multirow{2}{*}{$113 \pm 3$} \\
\hline & & & 2.80 & 94.6 & 6.22 & \\
\hline \multirow[t]{6}{*}{ 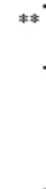 } & GdK-02 & $\mathrm{Hb}$ & 1.49 & 96.1 & 3.37 & \multirow{2}{*}{$112 \pm 3$} \\
\hline & & & 1.52 & 94.5 & 3.37 & \\
\hline & \multirow[t]{4}{*}{03082004} & $\mathrm{Hb}$ & 0.385 & 85.5 & 0.91 & \multirow{2}{*}{$107 \pm 3$} \\
\hline & & & 0.392 & 83.2 & 0.91 & \\
\hline & & $\mathrm{Bt}$ & 3.12 & 95.0 & 7.12 & \multirow{2}{*}{$109 \pm 3$} \\
\hline & & & 3.11 & 96.4 & 7.12 & \\
\hline \multirow{4}{*}{\multicolumn{2}{|c|}{03082104}} & $\mathrm{Hb}$ & 0.331 & 84.8 & 0.72 & \multirow{2}{*}{$113 \pm 3$} \\
\hline & & & 0.324 & 86.2 & 0.72 & \\
\hline & & $\mathrm{Bt}$ & 3.28 & 97.2 & 7.22 & \multirow{2}{*}{$113 \pm 3$} \\
\hline & & & 3.26 & 97.6 & 7.24 & \\
\hline
\end{tabular}

\begin{tabular}{|c|c|c|c|c|c|}
\hline Sample No. & $\begin{array}{c}\text { Material } \\
\text { Analyzed }\end{array}$ & $\begin{array}{c}{ }^{40} \mathrm{Ar} \mathrm{rad} \\
\left(\times 10^{-5} \mathrm{scc} / \mathrm{g}\right)\end{array}$ & $\begin{array}{c}{ }^{40} \mathrm{Ar} \mathrm{rad} \\
(\%)\end{array}$ & $\begin{array}{c}\mathrm{K} \\
(\%)\end{array}$ & $\begin{array}{c}\text { Isotopic } \\
\text { Age (Ma) }\end{array}$ \\
\hline \multirow[t]{2}{*}{03082105} & $\mathrm{Hb}$ & $\begin{array}{l}0.273 \\
0.278\end{array}$ & $\begin{array}{l}81.8 \\
82.2\end{array}$ & $\begin{array}{l}0.61 \\
0.61\end{array}$ & $113 \pm 3$ \\
\hline & $\overline{\mathrm{Bt}}$ & $\begin{array}{l}3.00 \\
2.08\end{array}$ & 96.4 & $\begin{array}{l}6.72 \\
670\end{array}$ & $111 \pm 3$ \\
\hline \multirow[t]{2}{*}{03082106} & $\mathrm{Hb}$ & $\begin{array}{c}2.98 \\
0.251 \\
0.257\end{array}$ & $\begin{array}{r}96.1 \\
74.0 \\
77.7\end{array}$ & $\begin{array}{l}6.70 \\
0.58 \\
0.58\end{array}$ & $109 \pm 3$ \\
\hline & $\mathrm{Bt}$ & $\begin{array}{l}3.09 \\
3.12\end{array}$ & $\begin{array}{l}96.3 \\
95.4\end{array}$ & $\begin{array}{l}7.23 \\
7.22\end{array}$ & $107 \pm 3$ \\
\hline \multicolumn{6}{|c|}{ Granitic rocks on western side of the HFZ } \\
\hline 03082001 & $\mathrm{Bt}$ & $\begin{array}{l}2.86 \\
2.87\end{array}$ & $\begin{array}{l}96.6 \\
96.2\end{array}$ & $\begin{array}{l}6.85 \\
6.85\end{array}$ & $105 \pm 3$ \\
\hline 03082002 & $\mathrm{Hb}$ & $\begin{array}{l}0.198 \\
0.199 \\
\end{array}$ & $\begin{array}{l}73.7 \\
70.1 \\
\end{array}$ & $\begin{array}{l}0.49 \\
0.49 \\
\end{array}$ & $101 \pm 3$ \\
\hline \multirow[t]{2}{*}{03082102} & $\mathrm{Hb}$ & $\begin{array}{l}0.294 \\
0.293 \\
\end{array}$ & $\begin{array}{l}87.9 \\
82.4 \\
\end{array}$ & $\begin{array}{l}0.67 \\
0.67 \\
\end{array}$ & $109 \pm 3$ \\
\hline & $\mathrm{Bt}$ & $\begin{array}{l}2.80 \\
2.78\end{array}$ & $\begin{array}{l}95.3 \\
96.1\end{array}$ & $\begin{array}{l}6.33 \\
6.35\end{array}$ & $110 \pm 3$ \\
\hline \multirow[t]{2}{*}{03082201} & $\mathrm{Hb}$ & $\begin{array}{l}0.274 \\
0.269\end{array}$ & $\begin{array}{l}76.2 \\
79.3\end{array}$ & $\begin{array}{l}0.63 \\
0.63\end{array}$ & $108 \pm 3$ \\
\hline & $\mathrm{Bt}$ & $\begin{array}{l}2.52 \\
2.54\end{array}$ & $\begin{array}{l}94.9 \\
94.2\end{array}$ & $\begin{array}{l}5.85 \\
5.84\end{array}$ & $108 \pm 3$ \\
\hline ** Gdo-01 & $\mathrm{Bt}$ & $\begin{array}{l}2.52 \\
2.51 \\
\end{array}$ & $\begin{array}{l}97.9 \\
98.5 \\
\end{array}$ & $\begin{array}{l}5.73 \\
5.73 \\
\end{array}$ & $110 \pm 5$ \\
\hline Gr-GSJ & $\mathrm{Bt}$ & $\begin{array}{l}2.52 \\
2.51 \\
\end{array}$ & $\begin{array}{l}90.9 \\
84.4 \\
\end{array}$ & $\begin{array}{l}2.55 \\
2.57 \\
\end{array}$ & $101 \pm 5$ \\
\hline * Gdy-GSJ & $\mathrm{Hb}$ & $\begin{array}{l}2.52 \\
2.51\end{array}$ & $\begin{array}{l}75.7 \\
88.9\end{array}$ & $\begin{array}{l}0.575 \\
0.586\end{array}$ & $95.7 \pm 4.8$ \\
\hline \multicolumn{6}{|c|}{ Dike intruding into the cataclasite zone } \\
\hline $\begin{array}{rr}\text { ** } & \text { Gdp-05 } \\
& (\mathrm{GdK}) \\
\end{array}$ & $\mathrm{Hb}$ & $\begin{array}{l}0.097 \\
0.099 \\
\end{array}$ & $\begin{array}{l}58.2 \\
56.8 \\
\end{array}$ & $\begin{array}{l}0.25 \\
0.25 \\
\end{array}$ & $98.1 \pm 2.5$ \\
\hline
\end{tabular}

Table 2. Fission-track analysis of zircon and apatite from the granitic rocks in the Hatagawa Fault Zone. Two fission-track ages of zircon and one age of apatite were measured for each sample. Fission-track samples were analyzed at Kyoto Fission-track Co., Ltd. by following the procedure described by Danhara et al. (2003).

\begin{tabular}{|c|c|c|c|c|c|c|c|c|c|c|c|c|c|c|c|}
\hline Sample & & $\begin{array}{l}\text { No. of } \\
\text { crystals }\end{array}$ & $\begin{array}{c}\rho_{s} \\
\left(\mathrm{~cm}^{-2}\right)\end{array}$ & $N_{s}$ & $\begin{array}{c}\rho_{i} \\
\left(\times 10^{6} \mathrm{~cm}^{-2}\right) \\
\end{array}$ & $N_{i}$ & $\begin{array}{c}\rho_{d} \\
\left(\times 10^{4} \mathrm{~cm}^{-2}\right) \\
\end{array}$ & $N_{d}$ & $r$ & $\begin{array}{c}\operatorname{Pr}\left(\chi^{2}\right) \\
(\%)\end{array}$ & $\begin{array}{c}U \\
(\mathrm{ppm})\end{array}$ & $\begin{array}{c}\text { Fission Track } \\
\text { Age } \pm 1 \sigma(\mathrm{Ma}) \\
\end{array}$ & $\begin{array}{c}\mathrm{L} \\
\mu \mathrm{m}\end{array}$ & $\mathrm{N}$ & $\begin{array}{c}\sigma \\
\mu \mathrm{m} \\
\end{array}$ \\
\hline \multirow[t]{3}{*}{03082004} & $\mathrm{Zr}$ & 30 & $9.18 \times 10^{6}$ & 4304 & 1.72 & 809 & 8.598 & 4402 & 0.512 & 28 & 190 & $86.3 \pm 3.6$ & 10.12 & 50 & 0.96 \\
\hline & $\mathrm{Zr}$ & 23 & $1.06 \times 10^{7}$ & 5969 & 2.12 & 1196 & 8.874 & 4543 & 0.715 & 0 & 230 & $83.6 \pm 3.0$ & & & \\
\hline & Ap & 30 & $6.05 \times 10^{5}$ & 662 & 1.11 & 1218 & 110.9 & 4435 & 0.678 & 24 & 12 & $* 100 \pm 5$ & & & \\
\hline \multirow[t]{3}{*}{03082103} & $\mathrm{Zr}$ & 30 & $1.14 \times 10^{7}$ & 5296 & 2.14 & 993 & 8.680 & 4444 & 0.612 & 30 & 230 & $87.4 \pm 3.4$ & 10.42 & 50 & 0.93 \\
\hline & $\mathrm{Zr}$ & 11 & $1.07 \times 10^{7}$ & 1585 & 2.22 & 329 & 8.892 & 4553 & 0.466 & 35 & 240 & $80.9 \pm 5.1$ & & & \\
\hline & Ap & 29 & $2.32 \times 10^{5}$ & 240 & 5.46 & 564 & 111.1 & 4445 & 0.481 & 9 & 6 & $78.7 \pm 6.3$ & & & \\
\hline \multirow[t]{3}{*}{03082105} & $\mathrm{Zr}$ & 30 & $9.49 \times 10^{6}$ & 4849 & 1.51 & 773 & 8.625 & 4416 & 0.690 & 48 & 170 & $102 \pm 4$ & 10.47 & 50 & 0.78 \\
\hline & $\mathrm{Zr}$ & 17 & $1.18 \times 10^{7}$ & 3751 & 2.51 & 794 & 8.880 & 4546 & 0.471 & 4 & 270 & $* 79.2 \pm 3.4$ & & & \\
\hline & Ap & 30 & $6.85 \times 10^{5}$ & 734 & 1.35 & 1452 & 111.0 & 4438 & 0.798 & 8 & 14 & $93.3 \pm 4.7$ & & & \\
\hline \multirow[t]{3}{*}{03082106} & $\mathrm{Zr}$ & 30 & $9.88 \times 10^{6}$ & 5493 & 1.70 & 945 & 8.652 & 4430 & 0.485 & 10 & 190 & $94.9 \pm 3.7$ & 10.62 & 50 & 0.67 \\
\hline & $\mathrm{Zr}$ & 24 & $1.09 \times 10^{7}$ & 5607 & 1.97 & 1016 & 8.886 & 4549 & 0.713 & 94 & 210 & $92.5 \pm 3.5$ & & & \\
\hline & Ap & 30 & $5.56 \times 10^{5}$ & 865 & 1.07 & 1659 & 111.0 & 4442 & 0.199 & 46 & 11 & $96.2 \pm 4.5$ & & & \\
\hline
\end{tabular}

*. Ages excluded from discussion; $\mathrm{Zr}$, zircon; Ap, apatite; $\rho_{s}$, spontaneous track density of a sample; $N_{x}$, number of tracks counted to determine $\rho_{s} ; \rho_{\mathrm{t}}$, induced track density of a sample measured in DAP external detector; $N_{i}$, number of tracks counted to determine $\rho_{i} ; \rho_{d}$, induced track density of glass dosimeter NIST-SRM612 measured in a DAP external detector; $N_{d}$, number of tracks counted to determine $\rho_{d} ; \mathrm{r}$, correlation coefficient between $\rho_{s}$ and $\rho_{i} ; \operatorname{Pr}\left(\chi^{2}\right)$, upper $\chi^{2}$ tail probability corresponding to the observed $\chi^{2}$-statistics (Galbraith, 1981); L, mean length of confined fission tracks; N, number of measured tracks to determine L; $\sigma$, standard deviation for the length distribution of confined fission tracks; Thermal neutrons were irradiated in the pneumatic tube of JRR-4 reactor unit of Japan Atomic Energy Research Institute.

side of the cataclasite zone in the northern area show a hornblende K-Ar age of $101 \pm 3 \mathrm{Ma}(03082002)$ and a biotite KAr age of $105 \pm 3 \mathrm{Ma}(03082001)$, which are younger than those of most of the samples.

Some K-Ar ages previously reported away from the HFZ show different ages from $110 \mathrm{Ma}$ (Fig. 1). In the eastern side of the HFZ (the South Kitakami belt), the sample GdW-GSJ gives a hornblende K-Ar age of 97.4 \pm 4.9 Ma. The sampling point of this sample is located in the center of the Kawabusa granodiorite. As two samples from the mar- gin of this pluton exhibit biotite $\mathrm{K}-\mathrm{Ar}$ ages of $104 \pm 5 \mathrm{Ma}$ (GdW-01) and 114 $\pm 6 \mathrm{Ma}$ (GdW-02) (Fig. 2), these K-Ar ages would indicate the difference of cooling in this pluton (Tomita et al., 2002). The sample GdK-GSJ away from the HFZ shows a hornblende K-Ar age of $126 \pm 6 \mathrm{Ma}$. Although this is the oldest $\mathrm{K}-\mathrm{Ar}$ age in this region, $\mathrm{K}-\mathrm{Ar}$ ages of two different samples (GdK-01, GdK-02) from the same pluton are about $110 \mathrm{Ma}$. In the western side of the HFZ (the Abukuma belt), Gdy-GSJ and Gr-GSJ far from the HFZ exhibit younger $\mathrm{K}-\mathrm{Ar}$ ages of $95.7 \pm 4.8 \mathrm{Ma}$ and $101 \pm 5 \mathrm{Ma}$ 
a

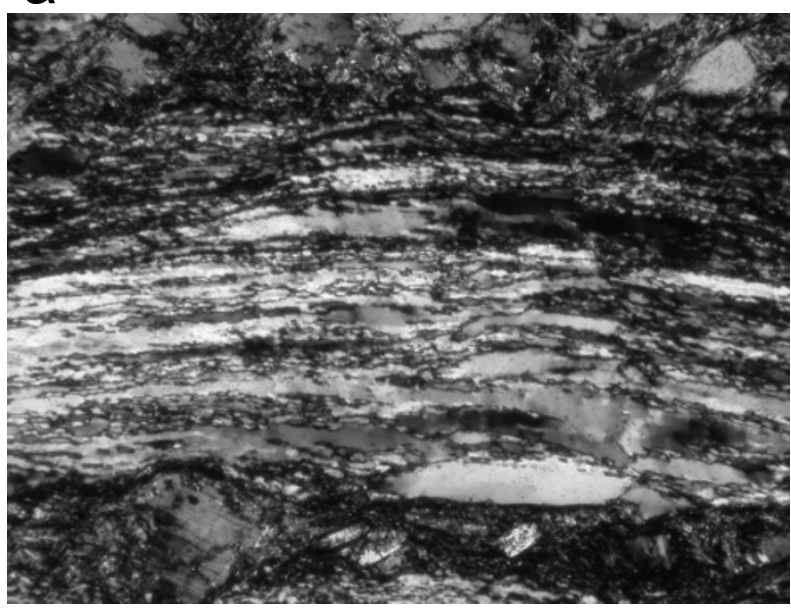

b

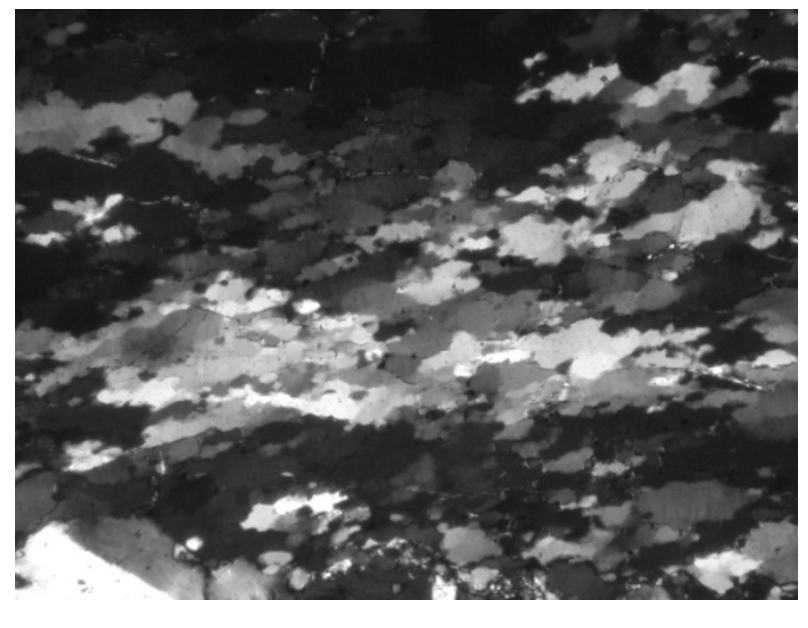

Fig. 3. Microstructure of the fault rocks from the Hatagawa Fault Zone. (a) Quartz microstructure of mylonite with microstructure A. Extremely elongated quartz grains with heavy undulatory extinction are surrounded by finer grains. (b) Quartz microstructure of mylonite with microstructure B. Aspect ratio of quartz grains does not depend on grain size. Scale bar is $0.1 \mathrm{~mm}$.

respectively.

Fission-track ages of zircon and apatite were measured for four samples (Table 2). We excluded unreliable fissiontrack ages based on the $\chi^{2}$-test and distinction between spontaneous tracks and dislocations. Spontaneous tracks in apatite grains of sample 03082004 are hard to distinguish from dislocations. Fission-track ages of apatite obtained from this sample were older than those of zircon. Thus the apatite fission-track age obtained from this sample is not reliable. One result of zircon from sample 03082105 failed the $\chi^{2}$-test at the $5 \%$ significance level, and this fissiontrack age (79.2 $\pm 3.4 \mathrm{Ma})$ is quite different from the other zircon fission-track age (102 $\pm 4 \mathrm{Ma})$ of the same sample. These two fission-track ages are excluded from the following discussion (Table 2). Although one result of zircon from sample 03082004 failed the $\chi^{2}$-test at the $5 \%$ significance level, this fission-track age corresponds with the other fission-track age of zircon from the same sample within the error range. We consider this fission-track age to be meaningful. Excluding the unreliable ages, fission-track ages of zircon from 4 samples range from $102 \pm 4$ to $80.9 \pm 5.1 \mathrm{Ma}$, and those of apatite show a range of $96.2 \pm 4.5$ to $78.7 \pm 6.3$ Ma. Average lengths of fission-track in zircon from 4 samples are 10.12 to $10.62 \mu \mathrm{m}$ and do not show obvious shortening.

The fission-track ages of zircon and apatite from the samples in and near the area where the low-T mylonites are developed (03082105 and 03082106) are older than those from the others (03082004 and 03082103) (Fig. 2). Three samples of them have also yielded K-Ar ages of hornblende and biotite. The differences of fission-track age of zircon and $\mathrm{K}-\mathrm{Ar}$ age of biotite from a single sample in and near the area where the low-T mylonites are developed are shorter than that of the high-T mylonites.

\section{Discussion}

The K-Ar systems of hornblende and biotite have different closure temperatures (Dodson and McClelland-Brown,
1985), and can be used to constrain the cooling history. Most of the granitic rocks in the HFZ show almost similar K-Ar ages within the error range of the dating except for a few samples, suggesting that granitic bodies cooled rapidly from closure temperature of hornblende to that of biotite. K-Ar dating along the HFZ reveals that the cooling history is almost the same along the strike of the HFZ, although granitic bodies represent multiple intrusions (Kubo and Yamamoto, 1990).

The closure temperatures of hornblende and biotite $\mathrm{K}$ Ar ages are $510 \pm 30^{\circ} \mathrm{C}$ (Dodson and McClelland-Brown, 1985) and $310 \pm 30^{\circ} \mathrm{C}$ (Harrison et al., 1985), and those of fission-track zircon and apatite are $280 \pm 30^{\circ} \mathrm{C}$ and $110 \pm 10^{\circ} \mathrm{C}$ (Stöckhert et al., 1999), respectively. These temperatures can be compared to the estimated deformation temperatures of high- $\mathrm{T}$ mylonites $\left(340^{\circ} \mathrm{C}\right.$ to $480^{\circ} \mathrm{C}$; Shigematsu et al., 2003), low-T mylonite $\left(300^{\circ} \mathrm{C}\right.$ to $360^{\circ} \mathrm{C}$; Shigematsu et al., 2003), and cataclasite $\left(220^{\circ} \mathrm{C}\right.$ to $300^{\circ} \mathrm{C}$; Tomita et al., 2002) (Fig. 4). These suggest that the formation of high-T mylonite started after approximately 110 $\mathrm{Ma}$, and the deformation conditions were rapidly changed into those of low-T mylonite. The cataclasis of the HFZ had eventually terminated by $98.1 \pm 2.5 \mathrm{Ma}$, as indicated by the K-Ar age of hornblende from an undeformed granodiorite porphyry dike intruded into the cataclasite zone (Tomita et al., 2002). Average lengths of fission-track in zircon do not show obvious shortening. Tagami and Shimada (1996) proposed a zircon partial annealing zone between $230^{\circ} \mathrm{C}$ to $330^{\circ} \mathrm{C}$. This suggests that the granitic rocks in the HFZ were not heated after the cooling to a temperature lower than $230^{\circ} \mathrm{C}$ and supports the formation of cataclasite and mylonite only during the cooling of the granitic bodies.

Shigematsu et al. (2003) estimated that plastic deformation was localized along the HFZ during the cooling of the granitic rock bodies from ca. 480 to $300^{\circ} \mathrm{C}$, and the distributed area of low-T mylonite represents the final localized area of plastic deformation. Although the K-Ar ages of hornblende and biotite do not show a significant difference 


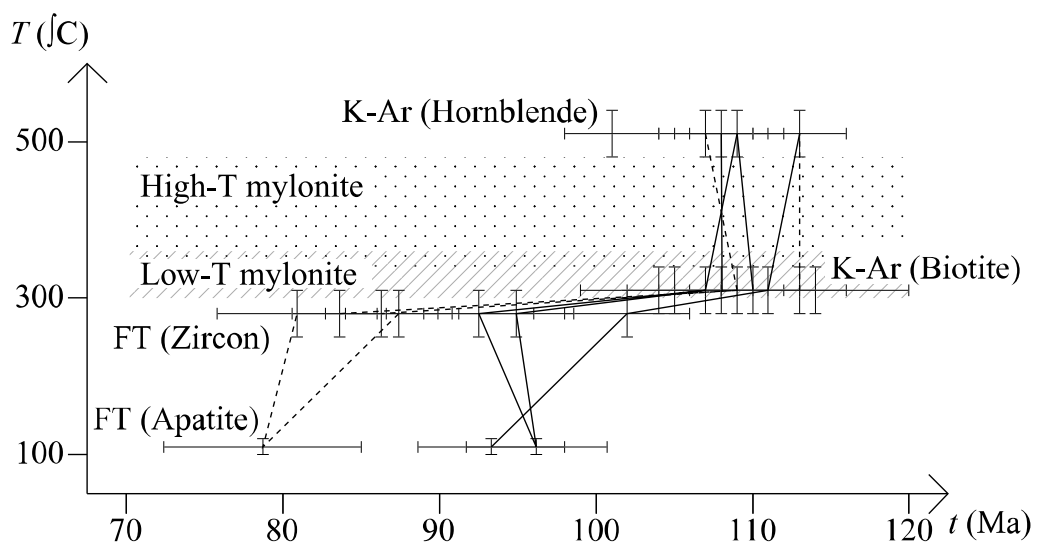

Fig. 4. Cooling history deduced from K-Ar and fission-track (FT) ages of granitic rocks in the Hatagawa Fault Zone. Connected lines between some ages mean that the ages were measured from the same sample. Solid and broken lines are cooling paths of low-T and high-T mylonites respectively. Closure temperatures of hornblende, biotite, zircon and apatite are $510 \pm 30^{\circ} \mathrm{C}$ (Dodson and McClelland-Brown, 1985), 310 $\pm 30^{\circ} \mathrm{C}$ (Harrison $\mathrm{et}$ al., 1985), $280 \pm 30^{\circ} \mathrm{C}$ and $110 \pm 10^{\circ} \mathrm{C}$ (Stöckhert et al., 1999) respectively.

between the temperatures for low-T and high-T mylonites, this does not exclude the possibility that the low-T mylonites formed after the high-T mylonite. The cooling histories deduced from the K-Ar ages, however, do not clearly show the regional temperature difference during mylonite formation due to the rapid cooling of the granitic rocks and the wide error range of the $\mathrm{K}-\mathrm{Ar}$ ages.

Mylonite samples on the western side of the cataclasite zone in the northern area show younger K-Ar ages of hornblende and biotite than those in other areas. This means that the western side of the northern area has a different cooling history. This different cooling history suggests that the granitic body had intruded later than those of the other areas or that the western side in the northern area had been exhumed from deeper part. K-Ar ages of hornblende and biotite of granitic rocks do not show their intrusion age, and it is difficult to infer which possibilities are reasonable for this different cooling history. In spite of the difference of the cooling history, the deformation temperature of the high-T mylonites in the western side of the northern area is almost the same as that of the other areas (Shigematsu et al., 2003). This suggests that, in either case, mylonite formation in this area occurred not at ca. $110 \mathrm{Ma}$ but probably later than that in the other areas.

The fission-track ages of zircon and apatite from samples 03082105 and 03082106 are older than those of the other samples, suggesting that the areas where the low-T mylonite is developed cooled more rapidly than the other areas at a temperature lower than the closure temperature of biotite. Low-T mylonites are often accompanied by crush zones in deformation-localized zones (Tomita et al., 2002). The rocks of the crush zones in deformation-localized zones have lower $\delta^{18} \mathrm{O}$ values than the weakly deformed rocks and other typical granitic rocks in Japan, and the most probable reason for the decrease in $\delta^{18} \mathrm{O}$ is interaction with nearsurface derived water (Fujimoto et al., 2002). Infiltration of near-surface derived water would accelerate cooling of granitic bodies, and this may be a possible reason why the areas where low-T mylonite is distributed cooled more rapidly than the other areas. Hornblende and K-feldspar are preserved in the low-T mylonites, suggesting that the low-
T mylonites formed under relatively dry condition (Shigematsu et al., 2003) based on the P-T diagram presented by Spear et al. (2002). Therefore rapid cooling of the area of the low-T mylonites would occur after plastic deformation in the HFZ.

A recent geophysical study of the Nagamachi-Rifu fault, NE Japan (Nakajima et al., 2001), pointed out the existence of low $P$-wave velocity $\left(V_{p}\right)$, low $S$-wave velocity $\left(V_{s}\right)$ and large $V_{p} / V_{s}$ zone caused by partially molten material beneath the downward extension of the seismogenic fault. A granitic pluton cooling after intrusion would be one possible material for this partially molten zone. The results of K-Ar and fission-track dating in this study suggest that the HFZ was deformed during cooling of the granitic plutons. Iio and Kobayashi (2002) suggested the possibility that aseismic slip on the downward extensions of the seismogenic faults of intraplate earthquakes accumulate stress on the seismogenic faults and accelerate before the large intraplate earthquakes. The mylonites in the HFZ might form by plastic deformation along a downward extension of a fault during cooling of granitic plutons and would play an important role in the understanding of large intraplate earthquakes.

\section{Conclusion}

The K-Ar dating of the granitic rocks in the HFZ revealed that (1) the cooling history from the closure temperature of hornblende to that of biotite is almost the same along the strike of the HFZ and among granitic bodies; (2) granitic rocks in the HFZ cooled rapidly from closure temperature of hornblende to that of biotite; (3) the formation of cataclasite and mylonite occurred during the cooling of the granitic bodies; (4) the formation of mylonite and cataclasite in the HFZ started after approximately $110 \mathrm{Ma}$ and terminated by 98.1 $\pm 2.5 \mathrm{Ma}$; (5) The cooling histories deduced from the $\mathrm{K}$-Ar ages do not clearly show regional temperature differences during mylonite formation.

The fission-track ages of zircon and apatite from the granitic rocks in the HFZ imply that the areas where low$\mathrm{T}$ mylonites are distributed cooled more rapidly than the other areas. This rapid cooling occurred at a temperature 
lower than closure temperature of biotite after plastic deformation, and infiltration of near-surface derived water may be a possible reason why the areas where low-T mylonites are distributed cooled more rapidly than the other areas.

Acknowledgments. We thank two anonymous reviewers and Richard Norris for their helpful reviews. This study is a part of a comprehensive research program on flow and slip processes in and below the seismogenic region sponsored by Ministry of Education, Culture, Sports, Science and Technology of Japan.

\section{References}

Danhara, T., H. Iwano, T. Yoshioka, and T. Tsuruta, Zeta calibration values for fission track dating with a diallyl phthalate detector, J. Geol. Soc. Japan, 109, 665-668, 2003.

Dodson, M. H. and E. McClelland-Brown, Isotopic and palaeomagnetic evidence for rates of cooling, uplift and erosion, Geol. Soc. London Mem., 10, 315-325, 1985.

Fujimoto, K., T. Ohtani, N. Shigematsu, Y. Miyashita, T. Tomita, H. Tanaka, K. Omura, and Y. Kobayashi, Water-rock interaction observed in the brittle-plastic transition zone, Earth Planets Space, 54, 11271132, 2002.

Galbraith, R. F., On statistical models for fission track counts, J. Math. Geol., 13, 471-478, 1981.

Harrison, T. M., I. Duncan, and I. McDougall, Diffusion of ${ }^{40} \mathrm{Ar}$ in biotite: temperature, pressure and compositional effects, Geochim. Cosmochim. Acta, 49, 2461-2468, 1985.

Iio, Y. and Y. Kobayashi, A physical understanding of large intraplate earthquakes, Earth Planets Space, 54, 1001-1004, 2002.

Kubo, K. and T. Yamamoto, Cretaceous intrusive rocks of Haramachi district, eastern margin of Abukuma Mountains-Petrography and K-Ar age, J. Geol. Soc. Japan, 96, 731-743, 1990 (in Japanese with English abstract).

Kubo, K., Y. Yanagisawa, T. Yoshioka, T. Yamamoto, and F. Takizawa, Geology of the Haramachi and Omika district with Geological Sheet Map at 1:50,000, Geological Survey of Japan, 155 pp., 1990 (in Japanese with English abstract).

Kubo, K., Y. Yanagisawa, T. Yoshioka, and Y. Takahashi, Geology of the Namie and Iwaki-Tomioka district with Geological Sheet Map at 1:50,000, Geological Survey of Japan, 104 pp., 1994 (in Japanese with English abstract).

Nakajima, J., T. Matsuzawa, A. Hasegawa, and D. Zhao, Threedimensional structure of $V_{p}, V_{s}$ and $V_{p} / V_{s}$ beneath northeastern Japan: Implication for arc magmatism and fluids, J. Geophys. Res., 106, 21843-21857, 2001.

Sendo, T., On the granitic rocks of Mt. Otakine and its adjacent districts in the Abukuma massif, Japan, Sci. Rep. Tohoku Univ. Third Series, 6,
$57-167,1958$

Shigematsu, N. and H. Yamagishi, Quartz microstructures and deformation conditions in the eastern Hatagawa shear zone, NE Japan, Island Arc, 11, 45-60, 2002.

Shigematsu, N., K. Fujimoto, T. Ohtani, H. Tanaka, Y. Miyashita, and T. Tomita, Structures of fault zones in the brittle-plastic transition zone of the continental earth's crust: A case study of the Hatagawa Fault Zone, J. Geogr. (CHIGAKUZASSHI), 112, 897-914, 2003 (in Japanese with English abstract).

Shigematsu, N., K. Fujimoto, T. Ohtani, and K. Goto, Ductile fracture of fine-grained plagioclase in the brittle-plastic transition regime: Implication for earthquake source nucleation, Earth Planet. Sci. Let., 222, 1007-1022, 2004.

Spear, F. S., M. J. Kohn, J. T. Cheney, and F. Florence, Metamorphic, thermal and tectonic evolution of central New England, J. Petrol., 43, 2097-2120, 2002.

Stöckhert, B., M. R. Brix, R. Kleinschrodt, A. J. Hurford, and R. Wirth, Thermochronometry and microstructures of quartz - a comparison with experimental flow laws and predictions on the temperature of the brittle-plastic transition, J. Struct. Geol., 21, 351-369, 1999.

Stormer, J. C., A practical geothermometer, Am. Mineral., 60, 674-677, 1975.

Tagami, T. and C. Shimada, Natural long-term annealing of the zircon fission track system around a granitic pluton, J. Geophys. Res., 101, 8245-8255, 1996.

Takagi, H., K. Goto, and N. Shigematsu, Ultramylonite bands derived from cataclasite and pseudotachylyte in granites, northeast Japan, J. Struct. Geol., 22, 1325-1339, 2000.

Tomita, T., T. Ohtani, N. Shigematsu, H. Tanaka, K. Fujimoto, Y. Kobayashi, Y. Miyashita, and K. Omura, Development of the Hatagawa Fault Zone clarified by geological and geochronological studies, Earth Planets Space, 54, 1095-1102, 2002.

Watanabe, I., Y. Sotozaki, and M. Gorai, Geology of the north eastern border district of northern Abukuma plateau, Sci. Rep. Tokyo Ed. Univ., 2, 69-78, 1953 (in Japanese with English abstract).

White, S., The effects of strain on the microstructures, fabrics, and deformation mechanisms in quarzites, Phil. Trans. Royal Soc. London, A283, 69-86, 1976.

Whitney, J. and J. C. Stormer, The distribution of $\mathrm{NaAlSi}_{3} \mathrm{O}_{8}$ between coexisting microcline and plagioclase and its effect on geothermometric calculation, Am. Mineral., 62, 687-691, 1977.

Yanagisawa, Y., T. Yamamoto, Y. Banno, T. Yoshioka, K. Kubo, and F. Takizawa, Geology of the Somanakamura district with Geological Sheet Map at 1:50,000, Geological Survey of Japan, 144 pp., 1996 (in Japanese with English abstract).

T. Ohtani (e-mail: tmohtani@cc.gifu-u.ac.jp), N. Shigematsu, K. Fujimoto, T. Tomita, H. Iwano 